\title{
DISCURSO PRONUNCIADO POR EL ALUMNO EGRESADO SR. ALEJANDRO VIADA OVALLE
}

"En verdad, ignoro por qué estoy tan triste. Me inquieta. Decís que a vosotros os inquieta también; pero cómo he adquirido esa tristeza, tropezado o encontrado con ella, de qué sustancia se compone, de dónde proviene, es lo que no acierto a explicarme. "William Shakespeare, el Mercader de Venecia, Acto primero, escena primera.

En este momento es difícil decir si estamos al final o al comienzo de una etapa y por lo mismo es que tenemos muchos sentimientos encontrados. Hace cinco años cruzamos el portal de estas aulas con la alegría y el temor de enfrentarnos a algo nuevo, quizás, al mayor desafío de nuestras vidas y hoy estamos por atravesar otra vez ese misma puerta, posiblemente con el mismo temor, pero ya no con esa alegría primitiva, sino con una tristeza que nos inquieta por lo pasado y por el porvenir.

La fragilidad de la memoria no ha sido lo suficientemente poderosa para borrar aquellos primeros días en que, maternalmente, fuimos recibidos por nuestra directora, la cual nos inició en el gratificante camino de ser un estudiante de derecho, enseñándonos un acto tan simple, pero a la vez tan significativo como fue el exclamar por primera vez el grito de nuestra escuela. Cómo no decir que en esos días eran muchas más las voces que nos acompañaban, algunas de las cuales están hoy con nosotros, pero también son varias las que con el tiempo se han ido apagando, ante lo cual no podemos sino evocar con cariño a esos compañeros que partieron con la idea de encontrar su verdadera vocación.

A poco andar, en estos primeros tiempos conocimos la parte cruda del estudio del derecho, fue a mediados del año 93 cuando nuestro recordado Padre Javier Ossa nos examinaba por primera vez, experiencia de dulce y agraz que se ha ido repitiendo todos los años hasta el día de hoy, en que hemos rendido nuestro último examen.

Tal como hoy, al cumplir la mitad de este camino tuvimos como motivo para celebrar el que el sol llegara al zenit de nuestra carrera y nos irradiara con esa sensación de saber que estábamos haciendo las cosas bien; en aquella oportunidad comprendimos que no obstante lo difícil del objetivo, valía la pena luchar y dar todo de nosotros para llegar juntos a la meta y estar hoy con ustedes.

Ahora, creemos que hemos pasado todas las vallas de nuestro estudio, creemos que es el momento de asumir nuevas responsabilidades, por lo tanto, anunciamos con mucho orgullo la formación del centro de ex alumnos de nuestra escuela y además la constitución de una comisión encargada de redactar los estatutos del mismo.

Es preciso decir que en todo este largo recorrido no hemos estado exentos de crítica, pero frente a éstas les respondemos que no hemos sido, como muchos creen, conejillos de indias, sino orgullosos PIONEROS que hemos llevado con tesón la bandera de nuestra escuela y la hemos clavado con firmeza en todos lo terrenos a los que hemos llegado. No nos cabe duda alguna que el nombre de nuestra alma mater quedará grabada en nuestros corazones y brillará cual estrella del norte en nuestras acciones, 
Revista de Derecho - Universidad Católica del Norte - Sede Coquimbo - 1998

alumbrando nuestra senda y la de las generaciones que nos siguen para fortalecer ésta, nuestra gran escuela. 